Jurnal ReviewPendidikan dan Pengajaran

http://journal.universitaspahlawan.ac.id/index.php/jrpp

Volume 2 Nomor 1, Juni 2019

P-2655-710X e-ISSN 2655-6022
Submitted : 07/05/2019

Reviewed :25/06/2019

Accepted :1/06/2019

Published :12/06/2019
Novelina

Andriani Zega ${ }^{1}$

\section{PENERAPAN MODEL PEMBELAJARAN KOOPERATIF TIPE TELAAH YURISPRUDENSI DALAM MENINGKATAN HASIL BELAJAR BIOLOGI SMA SWASTA PEMBDA 2 GUNUNGSITOLI}

\begin{abstract}
Abstrak
Penelitian ini bertujuan untuk Mendeskripsikan proses pembelajaran Biologi melalui penerapan model pembelajaran Kooperatif Tipe Telaah Yurisprudensi dan Mendeskripsikan hasil belajar siswa pada mata pelajaran Biologi melalui penerapan model pembelajaran Kooperatif Tipe Telaah Yurisprudensi Penelitian ini dilaksanakan di SMA Swasta Pembda 2 Gunungsitoli tahun pembelajaran 2018/2019. Penelitian ini adalah Penelitian Tindakan Kelas (PTK). Subjek penelitian kelas XI-IPA. Hasil penelitian adalah: 1) pelaksanaan proses pembelajaran Pada siklus I responden guru $50 \%$ pada pertemuan I dan $71,75 \%$ (Cukup) pada pertemuan II dengan nilai rata-rata 60,87\%. Angket kualitas pembelajaran siklus I mencapai 62,29\% (cukup) Sedangkan pada siklus II mencapai 93,75\% (baik sekali) pada pertemuan I dan mencapai kategori baik sekali dengan persentase $98,44 \%$ pada pertemuan II serta rata-rata 96,09\%. Angket kualitas pembelajaran mencapai kategori baik sekali dengan persentase nilai 89,50\%; 2) Nilai hasil rata-rata belajar pada siklus I sebesar 62,51 dan tergolong kurang dengan persentase ketuntasan 35,13\% dan ketidaktuntasan 64,87\%. Pada siklus II (kedua), nilai rata-rata hasil belajar 80,64 dan tergolong baik dengan persentase ketuntasan $86,48 \%$ dan ketidaktuntasan $13,52 \%$.
\end{abstract}

Kata Kunci: Model Pembelajaran, Kooperatif Tipe, Telaah, Yurisprudensi

\begin{abstract}
This study aims to describe the Biology learning process through the application of the Jurisprudence Type 2 Cooperative learning model and to describe student learning outcomes in Biology subjects through the application of the Cooperative learning model of the Jurisprudence Study Type. This research is Classroom Action Research (CAR). Class XI-IPA research subjects. The results of the study are: 1) the implementation of the learning process in the first cycle of teacher respondents $50 \%$ at the first meeting and $71.75 \%$ (enough) at the second meeting with an average value of $60.87 \%$. Questionnaire quality of learning cycle I reached $62.29 \%$ (enough) Whereas in cycle II it reached $93.75 \%$ (very good) at the first meeting and
\end{abstract}

\footnotetext{
${ }^{1}$ Prodi Pendidikan Biologi, IKIP Gunungsitoli

Alamat email: andrianizega84@gmail.com
} 
reached a very good category with a percentage of $98.44 \%$ at the second meeting and an average of $96.09 \%$. The learning quality questionnaire reached the excellent category with a percentage of values of $89.50 \%$; 2) The average value of learning outcomes in the first cycle was 62.51 and classified as poor with a percentage of completeness of $35.13 \%$ and incompleteness of $64.87 \%$. In the second cycle (second), the average value of learning outcomes is 80.64 and is classified as good with a percentage of completeness of $86.48 \%$ and $13.52 \%$ of completeness.

Keywords: Learning Model, Cooperative Type, Study, Jurisprudence

\section{PENDAHULUAN}

Pendidikan merupakan aspek penting dalam kehidupan manusia dan tidak bisa dipisahkan dari kehidupan itu sendiri. Kelembagaan dipergunakan untuk menyempurnakan perkembangan individu dalam menguasai pengetahuan, kebiasaan, sikap dan lain-lain. Perubahan dan perkembangan aspek kehidupan perlu ditunjang oleh kinerja pendidikan yang bermutu tinggi. Pendidikan yang berkualitas sangat diperlukan untuk mendukung terciptanya manusia yang cerdas serta mampu bersaing di era globalisasi. Pendidikan mempunyai peranan yang sangat besar dalam membentuk karakter, perkembangan ilmu dan mental seorang anak, yang nantinya akan tumbuh menjadi seorang manusia dewasa yang akan berinteraksi dan melakukan banyak hal terhadap lingkungannya, baik secara individu maupun sebagai makhluk sosial. Dengan pendidikan, manusia akan mendapat ilmu pengetahuan yang sangat bermanfaat bagi dirinya dalam kehidupan sehari-hari.

Sekolah sebagai salah satu lembaga pendidikan yang mempunyai peranan yang sangat besar dalam rangka menciptakan manusia yang beriman dan bertakwa kepada Tuhan Yang Maha Esa, bermoral, berakhlak mulia, cakap, kreatif, dan dapat mandiri. Secara formal pendidikan itu berlangsung di lingkungan sekolah dimana terdapat kerjasama yang baik antara guru dengan siswa dan antara siswa dengan siswa, baik secara individu maupun kelompok. Pelaksanaan pendidikan di sekolah dilakukan melalui pembelajaran kepada peserta didik dengan berbagai strategi, metode, maupun model pembelajaran (Dimyati, 2006). Berbagai macam strategi, metode maupun model pembelajaran tersebut dilaksanakan dalam pembelajaran dengan tujuan untuk memudahkan pemahaman peserta didik akan materi pembelajaran yang disampaikan dan juga untuk menciptakan suasana belajar yang kondusif serta meningkatkan kualitas dan cara belajar siswa sehingga diperoleh hasil yang memuaskan.

Terlepas dari hal tersebut diatas, kenyataan yang sering dijumpai di beberapa sekolah sekarang ini adalah rendahnya hasil belajar siswa. Hal ini disebabkan oleh berbagai macam penyebab yang sifatnya kompleks yang dapat bersumber dari berbagai aspek, baik dari diri peserta didik, lingkungan sekolah, guru, lingkungan masyarakat, maupun lingkungan keluarga.

Berdasarkan obserbasi yang dilakukan peneliti selama melakukan pembelajaran Biologi di SMA Swasta Pembda 2 Gunungsitoli diperoleh data sebagai berikut: terdapat 
beberapa siswa mengantuk pada saat proses belajar mengajar berlangsung; Kualitas belajar siswa pada mata pelajaran Biologi masih kurang; Sebagian siswa malas mengerjakan tugas Biologi; Kemampuan daya pikir siswa yang berbeda-beda; Keterbatasan guru dalam menciptakan suasana yang aktif dan menyenangkan; Kurangnya kemampuan dasar siswa dalam mengikuti proses pembelajaran Biologi karena keterbatasan sumber belajar bagi siswa; Nilai rata-rata hasil belajar siswa pada mata pelajaran Biologi masih tergolong kategori cukup.

Untuk mengatasi masalah tersebut maka salah satu upaya yang dilakukan adalah memperbaiki proses pembelajaran dengan penerapan model pembelajaran Kooperatif Tipe Telaah Yurisprudensi (Anita, 2008). Melalui penerapan model pembelajaran Kooperatif Tipe Telaah Yurisprudensi akan memberi kesempatan kepada siswa untuk bekerja sama dengan sesama siswa dalam tugas-tugas yang terstruktur (Isjoni, 2007). Kondisi pembelajaran juga diharapkan dapat memperbaiki proses pembelajaran serta hasil belajar siswa meningkat (Daryanto, 2009).

\section{METODE}

Dalam penelitian tindakan kelas (Arikunto, dkk, 2008), ada empat tahapan yang dilakukan oleh peneliti setiap pertemuan untuk setiap siklus yaitu sebagai berikut:

a. Perencanaan (Planning)

1). Setiap pertemuan peneliti menyiapkan:

a). Rencana Pelaksanaan Pembelajaran (RPP) sesuai dengan model pembelajaran kooperatif tipe Telaah Yurisprudensi

b). Kunci jawaban

c). Menyiapkan media pembelajaran

d). Lembar observasi

2). Setiap akhir siklus peneliti menyiapkan

a). Tes hasil belajar yang disusun berdasarkan kisi-kisi tes setiap akhir siklus

b). Kunci jawaban

c). Lembaran wawancara

d). Lembaran angket tentang proses pelaksanaan pembelajaran

\section{b. Tindakan (Action)}

Tindakan atau kegiatan merupakan tahapan dalam melaksanakan penelitian tindakan kelas. Berpedoman pada perencanaan di atas maka penulis melaksanakan tindakan sesuai dengan perencanaan atau planing yaitu kegiatan pembelajaran dengan penerapan model pembelajaran kooperatif tipe Telaah Yurisprudensi pada materi pokok sistem reproduksi pada manusia (Aqib, dkk, 2009).

\section{c. Pengamatan (Obsevation)}

Selama proses pembelajaran berlangsung, guru mata pelajaran sebagai pengamat memperhatikan kesesuaian langkah-langkah pelaksanaan pembelajaran dengan menerapkan model pembelajaran kooperatif tipe Telaah Yurisprudensi dan memperhatikan keaktifan atau keterlibatan siswa selama proses pembelajaran dengan menggunakan lembaran pengamatan (terlampir). (Zagoto, dkk., 2018; Sarumaha, 2018; Dakhi, O., 2013) 
Pelaksanaan wawancara dan pemberian angket akan dilakukan oleh peneliti setiap akhir siklus dan mengingat jumlah responden cukup banyak sedangkan waktu yang tersedia sangat terbatas, maka wawancara dilakukan pada satu orang siswa yang merupakan perwakilan dari setiap kelompok belajar yang terbentuk.

\section{d. Refleksi (Reflektion)}

Refleksi dilakukan dalam 2 dua tahap yaitu:

1). Setiap akhir pertemuan, peneliti sebagai guru merekapitulasi hasil observasi instrumen penelitian yang terdiri dari:

a) Lembar pengamatan proses pembelajaran

b) Lembar pengamatan siswa yang terlibat aktif dalam proses pembelajaran

c) Lembar pengamatan siswa yang tidak terlibat aktif dalam proses pembelajaran

2). Setiap akhir siklus, peneliti sebagai guru merekapitulasi hasil observasi instrumen penelitian yang terdiri dari:

a). Angket kualitas pembelajaran

b). Lembar panduan wawancara

c). Tes hasil belajar

Siklus kedua dilaksanakan apabila hasil yang telah dicapai pada siklus I tidak mencapai target yang telah ditentukan. Direncanakan pertemuan sebanyak dua kali ditambah satu kali pertemuan untuk memberi tes hasil belajar. Tindakan pada siklus II direncanakan sesuai dengan perencanaan pada siklus I.

Penelitian ini terdiri dari dua siklus, sebagai berikut:

a. Siklus I

Siklus I terdiri dari tiga kali pertemuan dan ditambah satu kali pertemuan untuk pemberian tes hasil belajar. Masing-masing pertemuan dilaksanakan pembelajaran dengan menerapkan model pembelajaran kooperatif tipe Telaah Yurisprudensi, setiap akhir pertemuan dilakukan refleksi. Selama siklus pertama berlangsung guru mata pelajaran Biologi sebagai pengamat, mengisi lembaran observasi sesuai langkah- langkah pembelajaran yang dilakukan, sedangkan peneliti sebagai pengajar. Setelah selesai pertemuan terakhir siklus I diadakan tes hasil belajar. Jika target sudah tercapai maka kegiatan penelitian selesai, tetapi jika tidak tercapai maka diungkap kekurangankekurangan pelaksanaan model pembelajaran kooperatif tipe Telaah Yurisprudensi berdasarkan data pada lembaran observasi.

Data ini digunakan untuk mengetahui apakah hasil belajar sudah mencapai kriteria ketuntasan minimal untuk kompetensi dasar yang telah diajarkan. Jika tidak tercapai kriteria maka dilanjutkan pada siklus II.

b. Siklus ke-2

Dengan mengevaluasi hasil siklus I, jika ternyata masih belum mencapai hasil yang diharapkan sebelumnya maka dapat dilanjutkan pada siklus II. Tindakan pada siklus II adalah menyempurnakan kekurangan-kekurangan yang ada pada siklus I. Pelaksanaan siklus II terdiri dari dua kali pertemuan dan ditambah satu kali pertemuan pemberian tes hasil belajar. 
Untuk mengumpulkan data pada penelitian ini digunakan instrumen penelitian, sebagai berikut :

a. Lembaran Observasi

Lembaran Observasi yang digunakan dalam penelitian ini terdiri dari tiga jenis yaitu:

1). Lembar pengamatan proses pembelajaran responden guru.

Lembaran pengamatan proses pembelajaran responden guru (peneliti) diadopsi dari

Kunandar (2007:234). Lembaran observasi ini digunakan sebagai alat untuk mengumpulkan data tentang kegiatan guru (peneliti) dalam proses pembelajaran. Kegiatan tersebut mencakup tentang kegiatan membuka pembelajaran, kemampuan menerapkan model pembelajaran kooperatif tipe Telaah Yurisprudensi, dan kegiatan menutup pembelajaran.

2). Lembar observasi untuk siswa-siswa yang tidak terlibat aktif dalam proses pembelajaran. Lembaran observasi ini diadopsi dari Kunandar (2007:232) dan digunakan untuk mengetahui bagaimana kegiatan siswa selama proses pembelajaran, khususnya siswa-siswa yang tidak aktif dalam pembelajaran. Kegiatan siswa yang dimaksud antara lain, mengantuk, mengerjakan tugas lain, berisik, keluar masuk kelas, mengganggu siswa lain, melamun, usil, coret-coret dikertas, nyeletuk, dan pindah-pindah tempat duduk.

3). Lembar pengamatan siswa yang aktif dalam kegiatan pembelajaran.

Lembaran observasi ini diadopsi dari Kunandar (2007:233) dan digunakan untuk mengetahui bagaimana keterlibatan siswa dalam proses pembelajaran yang terkait dengan, minat, perhatian, partisipasi, dan presentasi hasil kerja kelompok.

\section{b. Lembaran Panduan Wawancara}

Lembar panduan wawancara digunakan untuk mengetahui bagaimana respon/pendapat dari siswa tentang pembelajaran yang dilaksanakan dengan menggunakan model pembelajaran kooperatif tipe Telaah Yurisprudensi. Pelaksanaan wawancara akan dilakukan oleh peneliti setiap akhir siklus, dan mengingat jumlah responden cukup banyak sedangkan waktu yang tersedia sangat terbatas maka, wawancara hanya dilakukan pada sebagian siswa yang dianggap dapat mewakili siswa yang lain. Sebelum ditetapkan sebagai salah satu instrumen penelitian, lembaran panduan wawancara divalidasikan kepada tiga orang guru/dosen yang telah berpengalaman mengajar.

c. Angket

Angket ini merupakan instrumen kualitas pembelajaran yang disusun dalam bentuk tes uraian, di mana kepada responden akan diberikan beberapa butir soal. Selanjutnya responden diminta untuk memilih satu jawaban yang dianggap paling sesuai dengan apa yang mereka rasakan.

\section{d. Tes Hasil Belajar}

Tes hasil belajar siswa yang digunakan adalah tes uraian dan disusun berdasarkan kisi-kisi tes untuk mengukur keberhasilan atau hasil belajar siswa pada setiap akhir siklus. 
Dalam penelitian ini tes hasil belajar dilaksanakan setiap akhir siklus, yaitu akhir sklus pertama dan siklus kedua.

a). Tes Hasil Belajar Pada Siklus Pertama

Tes hasil belajar yang digunakan peneliti pada siklus pertama adalah berbentuk tes uraian sebanyak 5 (lima) butir soal dan disusun berdasarkan kisi-kisi tes.

b). Tes Hasil Belajar Pada Siklus Kedua

Tes hasil belajar pada siklus kedua yang digunakan berbentuk tes uraian sebanyak 5 butir dan disusun oleh peneliti berdasarkan kisi-kisi tes.

\section{HASIL DAN PEMBAHASAN}

Proses pembelajaran melalui penerapan model pembelajaran kooperatif tipe telaah yurisprudensi adalah Pada siklus I (pertama) hasil observasi pelaksanaan, pada pertemuan I persentase pengamatan proses pembelajaran responden guru mencapai 50,00\% atau kategori Refleksi Setiap Siklus I :

\section{1). Siklus I pertemuan I}

a). Rata-rata hasil pengamatan siswa yang tidak aktif mencapai $40,54 \%$

b). Rata-rata hasil pengamatan siswa yang aktif mengikuti pembelajaran $61,25 \%$

c). Hasil pengamatan proses pembelajaran responden guru $50 \%$.

Berdasarkan hasil observasi menunjukkan bahwa masih terdapat langkah- langkah pembelajaran dengan model pembelajaran Kooperatif tipe Telaah Yurisprudensi yang belum terlaksana dengan baik.

2). Siklus I, pertemuan II

a). Rata-rata hasil pengamatan siswa yang tidak aktif $29,72 \%$

b). Rata-rata hasil pengamatan siswa yang aktif mengikuti pembelajaran $65,75 \%$

c). Hasil pengamatan proses pembelajaran responden guru $71,75 \%$.

Hasil ini menunjukkan proses pembelajaran dengan menerapkan model pembelajaran Kooperatif tipe Telaah Yurisprudensi yang sudah cukup baik.

3). Akhir Siklus I

a). Rata-rata hasil belajar siswa 62,51 dengan kategori cukup dan persentase ketuntasan belajar siswa mencapai $35,13 \%$

b). Hasil angket kualitas pembelajaran $62,29 \%$

c). Hasil wawancara.

Berdasarkan hasil wawancara dengan siswa peneliti mendapatkan beberapa masukan dari kegiatan pembelajaran yang dilakukan selama ini, dimana siswa menyatakan bahwa belum pernah diterapkan model pembelajaran kooperatif tipe Telaah Yurisprudensi khususnya dalam pembelajaran Biologi.

Pada pertemuan pertama siswa merasa kaku dan tidak bisa mengerti tentang kegiatan yang dilakukan peneliti terlebih dalam bekerjasama dengan anggota dalam kelompok, tetapi pada pertemuan kedua siswa dapat melaksanakan kegiatan belajar dengan baik. Hal ini disebabkan karena guru/peneliti menggali argumentasi kepada eluruh siswa untuk aktif dalam kegiatan pembelajaran. Selain itu juga peneliti memberikan kebebasan kepada siswa untuk berdiskusi dan menjawab soal-soal yang bisa dikerjakan pada saat proses pembelajaran sehingga pada pemberian kuis siswa antusias dalam menjawab. 
4). Kesimpulan Pelaksanaan Siklus I

Berdasarkan rata-rata hasil Refleksi ternyata diperoleh 56,13\% dan hasil wawancara menyatakan bahwa masih terdapat kekurangan dalam proses pembelajaran serta hasil belajar siswa masih belum memenuhi target sehingga disimpulkan dilanjutkan pada siklus:

a. Refleksi Siklus II

1). Siklus II, pertemuan 1

a). Rata-rata hasil pengamatan siswa yang tidak aktif $21,62 \%$

b). Rata-rata hasil pengamatan siswa yang aktif mengikuti pembelajaran 91,25\%

c). Hasil pengamatan proses pembelajaran responden guru $93,75 \%$.

Hasil ini menunjukkan pelaksanaan proses pembelajaran dengan menerapkan model pembelajaran Kooperatif tipe Telaah Yurisprudensi semakin baik, langkah-langkah pembelajaran yang tergolong cukup pada siklus I menjadi baik pada siklus ini.

2). Siklus II, pertemuan II

a). Rata-rata hasil pengamatan siswa yang tidak aktif $16,21 \%$

b). Rata-rata hasil pengamatan siswa yang aktif mengikuti pembelajaran $95,00 \%$.

c). Hasil pengamatan proses pembelajaran responden guru $98,44 \%$

3). Akhir siklus II

a). Rata-rata hasil hasil belajar siswa 80,64 dengan kategori baik dan persentase ketuntasan belajar siswa mencapai $86,48 \%$

b). Hasil angket kualitas pembelajaran $89,50 \%$ dengan kategori baik

c). Hasil wawancara

Berdasarkan hasil wawancara dengan siswa dapat disimpulkan bahwa siswa merasa senang dan mempunyai minat dalam belajar khususnya pada mata pelajaran Biologi karena mereka mudah memahami dan mempalajari materi yang dipelajari dengan kerja kelompok. Siswa saling membantu antar anggota dalam kelompok belajar sehingga terjalin berinteraksi atau komunikasi yang baik antara siswa. Model pembelajaran Kooperatif tipe Telaah Yurisprudensi memberikan suasana belajar baru yakni pembelajaran yang aktif, kreatif dan menyenangkan bagi siswa dibanding dengan kegiatan pembelajaran yang terjadi selama ini yang bersifat konvensional.

4). Kesimpulan Pelaksanaan Siklus II

1. Berdasarkan rata-rata hasil refleksi ternyata diperoleh $75,65 \%$ mencapai target yang telah ditentukan (75\%), dan hasil wawancara menyatakan bahwa proses pembelajaran dengan menerapkan model pembelajaran Kooperatif tipe Telaah Yurisprudensi menumbuhkan motivasi dan rasa percaya diri siwa. Karena hasil belajar siswa telah mencapai target yang ditetapkan, maka permasalahan telah selesai. 


\section{Refleksi Siklus I}

\section{a. Refleksi Pertemuan I Siklus I}

Pembelajaran pada pertemuan I siklus I masih jauh dari yang diharapkan dimana persentase siswa yang tidak terlibat aktif dalam proses pembelajaran masih 40,54\%. Keterlibatan siswa secara aktif dalam proses pembelajaran juga masih tergolong kategori cukup dimana rata-rata persentase siswa yang terlibat aktif adalah 61,25\%. Demikian juga kemampuan peneliti yang bertindak sebagai guru dalam menerapkan model Pembelajaran Kooperatif Tipe Telaah Yurisprudensi masih tergolong kategori cukup dimana rata-rata persentase pengamatan proses pembelajaran hanya 50,00\%.

Kondisi pembelajaran pada pertemuan I siklus I yang masih tidak sesuai dengan yang diharapkan disebabkan oleh karena peneliti yang bertindak sebagai guru masih kaku karena belum terbiasa dalam mengajar terlebih untuk menerapkan model PembelajaranKooperatif Tipe Telaah Yurisprudensi. Siswa merasa terkejut dengan pembelajaran yang dilaksanakan oleh peneliti karena selama ini siswa terbiasa dengan pembelajaran konvensional. Siswa juga terkesan kurang mempedulikan arahan peneliti karena mereka merasa tidak ada pengaruh penelitian pada nilai mata pelajaran.

Untuk memperbaiki kondisi pembelajaran pada pertemuan I siklus I maka pada pertemuan II siklus I peneliti mempersiapkan diri dengan lebih baik lagi. Beberapa cara yang dilakukan peneliti, antara lain: membangun komunikasi yang baik dengan siswa, memberi perhatian yang lebih banyak kepada siswa yang mengantuk, mengerjakan tugas lain, berisik, keluar masuk kelas, mengganggu siswa lain, melamun, usil, coret - coret, nyeletuk, pindahpindah tempat duduk, memberikan pujian kepada siswa yang lebih aktif, meminta bantu kepada guru mata pelajaran untuk mengarahkan siswa yang tidak peduli dengan proses pembelajaran.

b. Refleksi Pertemuan II Siklus I

Pembelajaran pada pertemuan II siklus I juga masih jauh dari yang diharapkan tetapi sudah mengalami kemajuan dimana persentase siswa yang tidak terlibat aktif dalam proses pembelajaran berkurang dari 40,54\% menjadi $29,72 \%$. Keterlibatan siswa secara aktif dalam proses pembelajaran juga semakin baik dimana rata-rata persentase siswa yang terlibat aktif adalah $65,75 \%$. Demikian juga kemampuan peneliti yangbertindak sebagai guru dalam menerapkan model Pembelajaran Kooperatif Tipe Telaah Yurisprudensi meningkat dari rata-rata persentase proses pembelajaran 50,00\% menjadi $70,75 \%$. 
Kondisi pembelajaran pada pertemuan II siklus I sudah sedikit lebih baik dari pertemuan I siklus I meskipun belum memenuhi target yang diharapkan. Meskipun pada pertemuan II ada peningkatan tetapi masih terdapat beberapa kekurangan dan kelemahan yang terjadi dalam proses pembelajaran. Peneliti yang bertindak sebagai guru masih belum menguasai secara maksimal langkahlangkah model Pembelajaran Kooperatif Tipe Telaah Yurisprudensi seperti teknik mengajukan pertanyaan, kemampuan membimbing kelompok dan teknik pemberian penghargaan (Nurhadi, 2004). Siswa masih kurang serius dalam melaksanakan diskusi kepada teman kelompoknya.

c. Refleksi Akhir Siklus I

Pada akhir siklus I dihitung rata-rata hasil observasi pada setiap pertemuan. Rata-rata persentase siswa yang tidak terlibat aktif pertemuan I dan pertemuan II siklus I adalah $35,13 \%$. Rata-rata persentase siswa yang terlibat aktif pertemuan I dan pertemuan II siklus I adalah 63,50\%. Hal ini belum memenuhi target yang ditetapkan yaitu minat, perhatian, partisipasi dan presentasi minimal baik. Pertemuan I dan pertemuan II siklus I diketahui ratarata persentase proses pembelajaran adalah 60,87 tergolong cukup. Hal ini berarti kemampuan peneliti yang bertindak sebagai guru dalam menerapkan model Pembelajaran Kooperatif Tipe Telaah Yurisprudensi belum maksimal. Hasil angket kualitas pembelajaran pada siklus I yang hanya mencapai 62,29\%.

Rata-rata hasil belajar pada siklus I adalah $62,51 \%$ masih tergolong kategori cukup dan persentase ketuntasan belajar siswa pada siklus I hanya $35,13 \%$. Hal ini belum memenuhi target yang ditetapkan untuk hasil belajar yaitu rata-rata hasil belajar minimal baik dan persentase ketuntasan belajar siswa minimal $75 \%$.

Dari hasil wawancara dengan beberapa orang siswa peneliti memperoleh informasi bahwa sebenarnya siswa cukup senang dengan pembelajaran yang dilaksanakan oleh peneliti yang bertindak sebagai guru hanya saja siswa belum terbiasa dan masih kaku dalam berinteraksi dengan anggota kelompok. Dari refleksi siklus I ternyata target yang diharapkan belum tercapai. Oleh sebab itu maka peneliti menyimpulkan bahwa penelitian dilanjutkan pada siklus II. Pada siklus II dilakukan beberapa perbaikan pada proses pembelajaran dengan meningkatkan minat belajar siswa dan menciptakan situasi kelas yang lebih kondusif. Peneliti optimis bahwa proses pembelajaran pada siklus II akan lebih baik karena peneliti yang bertindak sebagai guru dan juga siswa sudah mulai terbiasa dengan model Pembelajaran Kooperatif Tipe Telaah Yurisprudensi. 


\section{Refleksi Siklus II}

\section{a. Refleksi Pertemuan I Siklus II}

Pembelajaran pada pertemuan I siklus II semakin baik dimana persentase siswa yang tidak terlibat aktif dalam proses pembelajaran hanya $21,62 \%$. Keterlibatan siswa secara aktif dalam proses pembelajaran juga rata-rata sudah baik dimana rata-rata persentase siswa yang terlibat aktif dalam proses pembelajaran mencapai $91,25 \%$. Demikian juga kemampuan peneliti yang bertindak sebagai guru dalam menerapkan model Pembelajaran Kooperatif Tipe Telaah Yurisprudensi mencapai rata-rata 93,75\% tergolong baik.

Kondisi pembelajaran pada pertemuan I siklus II sudah baik. Siswa sangat antisias dalam melaksanakan pembelajaran dengan diskusi kelompok. Meskipun demikian peneliti tetap melanjutkan pada pertemuan II karena siklus II direncanakan dua kali pertemuan. Seandainya tidak dilanjutkan maka tidak semua materi pelajaran yang direncanakan untuk disajikan tercapai sehingga sulit untuk memberikan tes hasil belajar. Selain itu, peneliti juga hendak memastikan bahwa hasil refeksi pertemuan I siklus II yang sudah mencapai kategori baik bukan hanya faktor kebetulan. Pada pertemuan II siklus II peneliti mempertahankan kondisi pembelajaran agar tetap baik.

\section{b. Refleksi Pertemuan II Siklus II}

Pembelajaran pada pertemuan II siklus II semakin baik dimana persentase siswa yang tidak terlibat aktif dalam proses pembelajaran hanya $16,21 \%$. Keterlibatan siswa secara aktif dalam proses pembelajaran juga ratarata sudah baik dimana rata-rata persentase siswa yang terlibat aktif dalam proses pembelajaran mencapai $95,00 \%$. Demikian juga kemampuan peneliti yang bertindak sebagai guru dalam menerapkan model Pembelajaran Kooperatif Tipe Telaah Yurisprudensi mencapai rata-rata 98,44\% tergolong baik.

Kondisi pembelajaran pada pertemuan II siklus II yang tetap baik merupakan indikasi bahwa pencapaian pada pertemuan II siklus II bukan faktor kebetulan melainkan proses pembelajaran menggunakan model Pembelajaran Kooperatif Tipe Telaah Yurisprudensi sudah benar-benar baik dan terperbaiki. Setelah pertemuan II siklus II diberikan angket kualitas pembelajaran, diberikan tes hasil belajar, dilakukan wawancara dengan beberapa orang siswa dan dilakukan refleksi akhir siklus II. 


\section{c. Refleksi Akhir Siklus II}

Pada akhir siklus II dihitung rata-rata hasil observasi pada setiap pertemuan. Rata-rata persentase siswa yang tidak terlibat aktif dari pertemuan I dan pertemuan II adalah 18,91\%. Rata-rata persentase siswa yang terlibat aktif pertemuan I dan pertemuan II siklus II adalah 93,12\%. Dari pertemuan I dan pertemuan II siklus II diketahui rata-rata proses pembelajaran adalah 96,09\% tergolong baik. Hal ini berarti kemampuan peneliti yang bertindak sebagai guru dalam menerapkan model Pembelajaran Kooperatif Tipe Telaah Yurisprudensi sudah maksimal. Hal ini dipertegas oleh hasil angket kualitas pembelajaran pada siklus II yang sudah mencapai $89,50 \%$ tergolong kategori baik sekali. Rata-rata hasil belajar pada siklus II adalah 80,64 dan tergolong kategori baik dan persentase ketuntasan belajar siswa pada siklus II mencapai $86,48 \%$. Hal ini telah memenuhi target yang ditetapkan untuk hasil belajar yaitu rata-rata hasil belajar minimal baik dan persentase ketuntasan belajar siswa minimal $75 \%$.

\section{SIMPULAN}

Dari hasil wawancara dengan beberapa orang siswa peneliti memperoleh informasi bahwa siswa sangat senang dengan pembelajaran yang dilaksanakan oleh peneliti yang bertindak sebagai guru menggunakan model Pembelajaran Kooperatif Tipe Telaah Yurisprudensi. Sehingga siswa mengharapkan agar proses pembelajaran seperti ini tetap dipertahankan antara lain: (1). Mendekati cukup, pada pertemuan II sebesar $71,75 \%$ berada pada interval cukup dan baik. Berdasarkan hasil angket kualitas proses pembelajaran mencapai $62,29 \%$ dengan kategori cukup. Sedangkan pada siklus II (kedua) hasil observasi pelaksanaan proses pembelajaran melalui penerapan model pembelajaran kooperatif tipe telaah yurisprudensi, pada pertemuan I persentase pengamatan responden guru mencapai $93,75 \%$ atau kategori baik, pada pertemuan II sebesar $98,44 \%$ berada pada interval baik dan sangat baik. Berdasarkan hasil angket mencapai 89,50\% dengan kategori baik; dan (2). Nilai rata-rata hasil belajar siswa Pada siklus I (pertama) sebesar 62,51 diklasifikasikan dengan kriteria tergolong cukup dan persentase ketuntasan hasil belajar siswa sebesar 35,13\% masih belum mencapai target yang ditetapkan sedangkan pada siklus II (kedua) rata-rata hasil belajar siswa adalah 80,64 diklasifikasikan dengan kriteria tergolong baik dan persentase ketuntasan hasil belajar siswa adalah $86,48 \%$ telah mencapai target yang ditetapkan.

\section{SARAN}

Berdasarkan temuan penelitian, pembahasan dan kesimpulan dalam penelitian ini maka beberapa saran dari peneliti yaitu sebagai berikut: (1). Guru yang mengajar perlu merencanakan strategi, metode dan model pembelajaran yang tepat dengan memperhatikan materi yang akan dibelajarkan kepada siswa; 
(2). Guru diharapkan mampu mencari solusi jika hasil belajar tidak sesuai dengan harapan artinya guru dituntut untuk kreaktif dan perlu memikirkan upaya-upaya yang dilakukan untuk meningkatkan hasil belajar siswa; dan (3). Guru dianjurkan agar jeli dan punya kompetensi dalam menggunakan strategi, metode dan model pembelajaran yaitu dengan menerapkan model pembelajaran kooperatif tipe Telaah Yurisprudensi

\section{DAFTAR PUSTAKA}

Arikunto, Suharsimi, dkk., 2008, Penelitian Tindakan Kelas, Bumi Aksara, Jakarta.

Aqib, Zainal, dkk, 2009, Penelitian Tindakan Kelas, Yrama Widya, Bandung.

Dakhi, O. "Aplikasi Pendeteksian Kerusakan File Akibat Virus Dengan Menggunakan Metode Heuristic." Pelita Informatika Budi Darma, vol. 4, no. 1, pp. 35-41, 2013.

Dakhi, O. 2013. Belajar Javascript Dengan Mudah Dan Detail. Jakarta: Dapur Buku. pp. 1-202.

Isjoni, 2007, Cooperative Learning Efektifitas Pembelajaran Kelompok, Alfabeta, Bandung.

Kunandar, 2008, Langkah Mudah Penelitian Tindakan Kelas Sebagai Pengembangan Profesi Guru, PT. Raja Grafindo Persada, Jakarta.

Lie, Anita, 2008, Cooperatif Learning Mempraktekkan Cooperatif Learning di Ruangruang Kelas, Grasindo, Jakarta.

Nurhadi, 2004, Kurikulum 2004 Pertanyaan dan Jawaban, Gramedia Widiasarana, Jakarta.

Sarumaha, R., Harefa, D., \& Zagoto, Maria M. (2018). Upaya Meningkatkan Kemampuan Pemahaman Konsep Geometri Transformasi Refleksi Siswa Kelas XII-IPA-B SMA Kampus Telukdalam Melalui Model Pembelajaran Discovery Learning Berbantuan Media Kertas Milimeter. Jurnal Education and development, Vol.6 No.1, 90-96. https://doi.org/10.37081/ed.v6i1.668

Slavin, Robert E., 2010, Cooperative Learning Teori, Riset dan Praktik, Nusa Media, Bandung.

Uno, Hamzah B, 2009, Model Pembelajaran, Menciptakan Proses Belajar Mengajar yang Kreatif dan Efektif, Bumi Aksara, Jakarta.

Usman, Moh. Uzer, 2006, Menjadi Guru Profesional, PT. Remaja Rosdakarya, Jakarta.

Wahyudin, Dinn, dkk., 2007, Pengantar Pendidikan, Universitas Terbuka, Jakarta. Wiriaatmadja, Rochiati, 2009, Metode Penelitian Tindakan Kelas, PT. Remaja Rosdakarya, Bandung.

Zagoto, Maria M., Yarni, Nevi; Dakhi, O. (2019). Perbedaan Individu dari Gaya Belajarnya Serta Implikasinya Dalam Pembelajaran. Jurnal Review Pendidikan dan Pengajaran, 2(2), 259265.

Zagoto, Maria M. \& Dakhi, O (2018). Pengembangan Perangkat Pembelajaran Matematika Peminatan Berbasis Pendekatan Saintifik Untuk Siswa Kelas XI Sekolah Menengah Atas. Jurnal Review Pendidikan dan Pengajaran, 1(1), 157-170.

Zagoto, Maria M. (2018). Pengembangan Perangkat Pembelajaran Matematika Berbasis Realistic Mathematic Educations Untuk Siswa Kelas V Sekolah Dasar, Jurnal Education And Development, vol. 3, no. 1, p. 53, Feb. 2018. https://doi.org/10.37081/ed.v3i1.139 